\title{
Níveis e dimensões \\ da renovação urbana \\ da Região da Luz: \\ da experiência da espoliação à luta de classes socioespacial
}

\author{
Guilherme Moreira Petrella*
}

\begin{abstract}
Resumo A Região da Luz, centro de São Paulo, é alvo de diversos planos de renovação urbana desde os anos 1970, que visam reverter o processo de degradação socioespacial. Dentre esses planos, os propostos no século XXI convergem por suas formas de atuação: reestruturação espacial no imbricamento imobiliário e infraestrutura realizado através de parcerias público privadas, que centralizam capitais produtivos (real), capitais improdutivos (fictício) e Estado (leis, financiamentos, políticas públicas e monopólio do uso da violência). Eles orientam para a constituição imediata do complexo imobiliário financeiro global. Porém, apesar das estratégias arquitetônicas e urbanísticas conceberem diferenciações formais relativas às diferenciações sociais, sua «verdade» é a viabilidade econômica. Neste sentido o «direito à moradia» aparece e se realiza como «direito à propriedade».
\end{abstract}

Palavras-chave: renovação urbana, renda capitalizada, direito à cidade.

\section{Niveles y dimensiones de la renovación ur- bana en la Región de la Luz: de la experiencia de la espoliacion a la lucha de clases socioespaciales}

\begin{abstract}
Resumen La Región de la Luz, centro de São Paulo, ha sido objeto de varios planes de renovación urbana desde la década de 1970, que apuntan a revertir el proceso de degradación socioespacial. Entre estos planes confluyen los propuestos en el siglo XXI por sus formas de actuación: reestructuración espacial en el traslapo inmobiliario e infraestructura realizada a través de alianzas público-privadas, que centralizan el capital productivo, el capital improductivo y el Estado. Guían la constitución inmediata del complejo inmobiliario financiero global. Sin embargo, a pesar de las estrategias arquitectónicas y urbanísticas que conciben diferenciaciones formales relativas a diferenciaciones sociales, su "verdad" es la viabilidad económica: el "derecho a la vivienda" aparece y se realiza como un "derecho a la propiedad".
\end{abstract}

Palabras clave: renovación urbana, ingresos capitalizados, derecho a la ciudad.

\begin{abstract}
Levels and dimensions of urban renewal in the region of luz: from the experience of spoliation to the struggle of socio-spatial classes

Abstract The Region of Luz, downtown São Paulo, has been the target of several urban renewal plans since the 1970s, which aim to reverse the process of socio-spatial degradation. Among these plans, those proposed in the 21st century converge due to their forms of action: spatial restructuring in the real estate overlap and infrastructure carried out through public-private partnerships, which centralize productive capital, unproductive capital and the State. They guide to the immediate constitution of the global financial real estate complex. However, despite the architectural and urban strategies that conceive formal differentiations relative to social differentiations, their "truth" is economic viability. In this sense, the "right to housing" appears and is realized as a "right to property".
\end{abstract}

Keywords: urban renovation, capitalized income, right to the city. 
A região da Luz, no centro de São Paulo, tem sido objeto de inúmeros planos urbanos desde os anos 1970. Planos que visam conter e reconverter a degradação socioambiental iniciada a partir dos anos 1940 em um processo paralelo à urbanização da metrópole, à expansão de seus limites baseada no predomínio do sistema rodoviário de mobilidade, na industrialização, na alta taxa de exploração e espoliação da força de trabalho. Nesta urbanização é acentuada a oferta de produtos imobiliários diferenciados, acentuando a obsolescência da região da Luz.

A cada época, uma estratégia.

Inicialmente, nos anos 1970-1980, a estratégia de renovação urbana baseava-se na demolição e construção massivas de unidades imobiliárias e infraestruturas. A construção, a lucratividade decorrente da extensão da produção, encontrava um entrave na propriedade, na rentabilidade decorrente do pagamento pelo uso do espaço. Como questionamento, foi se configurando a "irracionalidade" desta (des)construção massiva, acompanhada pela necessidade de investimentos financeiros vultuosos, irreais, além da possibilidade de descaracterização do tecido urbano existente, representado pela especificidade patrimonial da região da Luz. A necessidade de se conservar o valor do patrimônio histórico e artístico se colocou como barreira à expansão massiva das demolições.

Posteriormente, nos anos 1990-2000, é justamente este aspecto cultural que permitiria a retomada imobiliária da região. Apoiado sobre um valor socialmente legítimo, a intervenção pontual em edifícios notáveis descolaria os benefícios econômicos da revitalização dos seus custos imediatos de produção. Assim começa a se iluminar o aspecto mistificador e fictício, através da cultura, como alavanca da valorização imobiliária e sua apreciação, ao se beneficiar de uma especificidade patrimonial em relação a outras regiões da metrópole. Como entrave, contudo, foi se configurando justamente a parcialidade deste tipo de intervenção, tanto em seu aspecto produtivo, quanto social. O retorno econômico esperado, em comparação com as facilidades de outras regiões da metrópole, livres de constrangimentos materiais e sociais do ambiente construído, não eram suficientes para atrair o interesse do ente privado, o meio de sua realização. Passou a ser necessário, portanto, criar outras formas para dar segurança ao investimento privado a partir da instrumentalização do público. Neste processo, permitiu-se tanto o acesso privilegiado à estrutura estatal de gestão, financiamento e legislação, quanto à expansão da exploração econômica de serviços e infraestruturas localizadas na esfera pública. Nesta transformação, a produção e o consumo se deslocaram do cultural para o social.

* Guilherme Moreira Petrella é Arquiteto e Urbanista, Professor da Unifesp Zona Leste - Instituto das Cidades, ORCID <http://orcid. org/0000-0003-3882-2109>.
Os planos urbanos recentes, aqui nomeados como planos do século XXI, buscam a reestruturação do espaço associada à reestruturação política e econômica mais ampla. Eles operam por um duplo movimento: de escassez e de expansão. Como escassez, entende-se a monopolização de um determinado perímetro urbano, que é assegurado por parcerias público-privada constituídas a partir de licitações e contatos. 

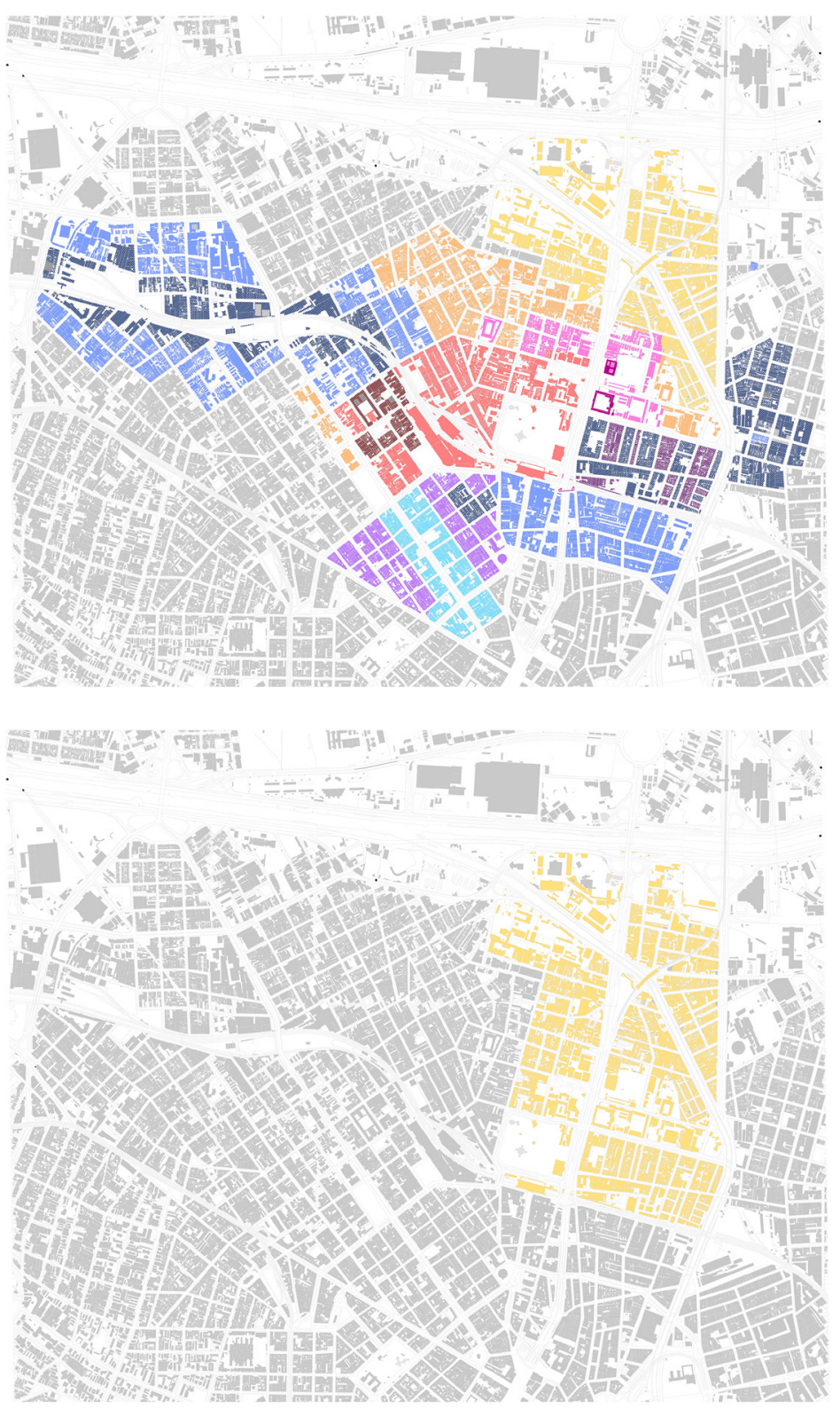

Mapa 1: PLANOS LUZ. Fonte: PETRELLA, 2017 (Elaboração do autor sobre base do MDC, Mapa Digital da Cidade de São Paulo).

Mapa 3: RENOVAÇÃO URBANA_1974. Fonte: PETRELLA, 2017 (Elaboração do autor sobre base do MDC, Mapa Digital da Cidade de São Paulo).

Mapa 4: LUZ CULTURAL_1984. Fonte: PETRELLA, 2017 (Elaboração do autor sobre base do MDC, Mapa Digital da Cidade de São Paulo).
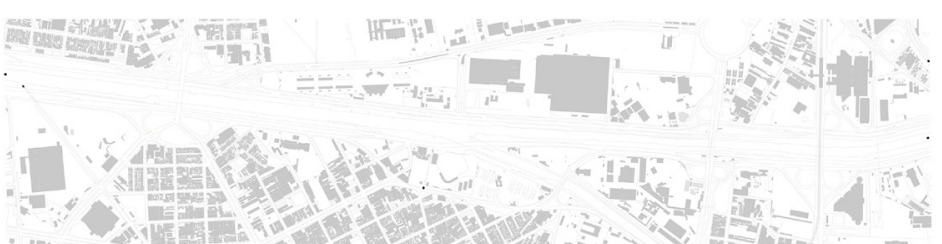

Q7n A.

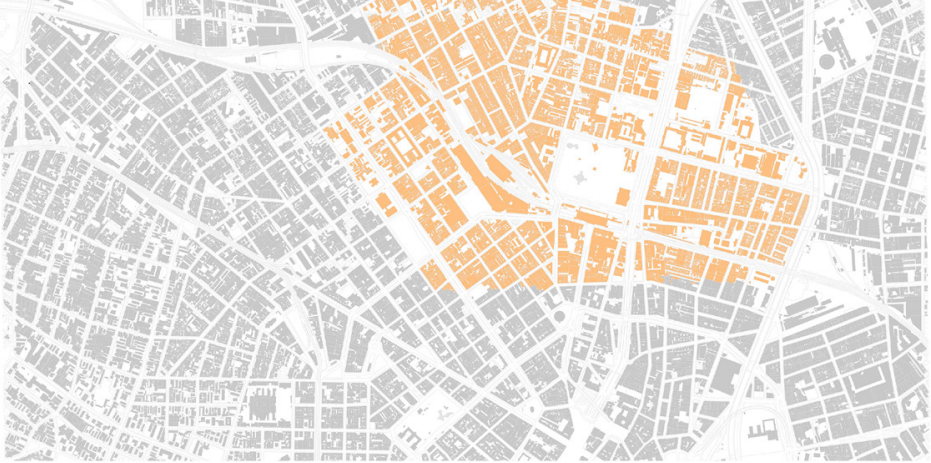



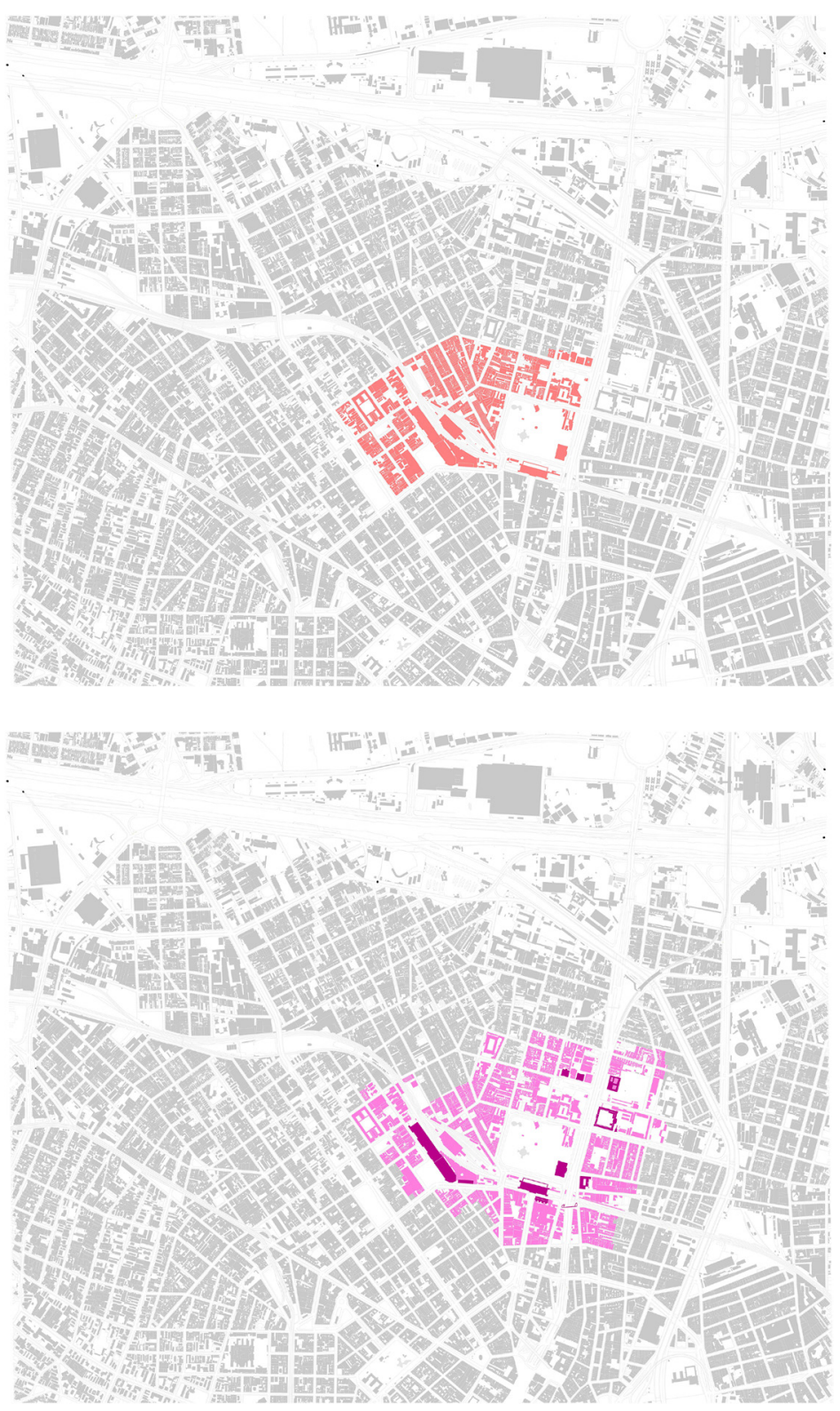

Mapa 5: POLO LUZ_1996. Fonte: PETRELLA, 2017 (Elaboração do autor sobre base do MDC, Mapa Digital da Cidade de São Paulo).

Mapa 6: MONUMENTA_2002. Fonte: PETRELLA, 2017 (Elaboração do autor sobre base do MDC, Mapa Digital da Cidade de São Paulo).

Mapa 7: PRIHLUZ_2004. Fonte: PETRELLA, 2017 (Elaboração do autor sobre base do MDC, Mapa Digital da Cidade de São Paulo).

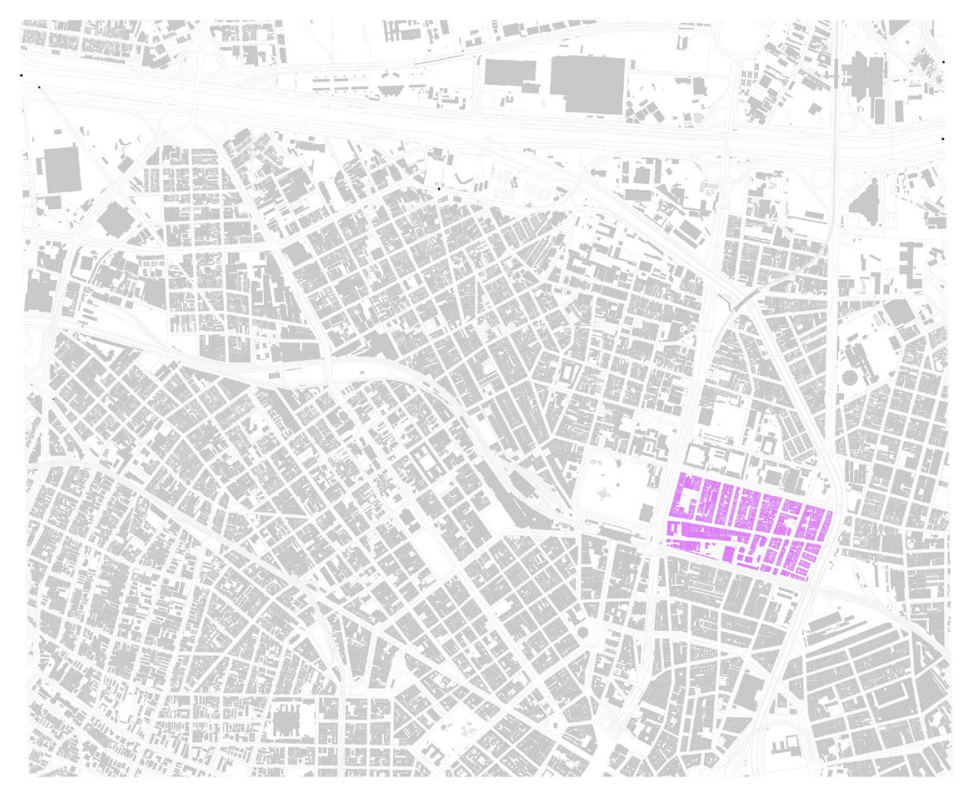


Mapa 2: PLANOS SECULO XXI. Fonte: PETRELLA, 2017 (Elaboração do autor sobre base do MDC, Mapa Digital da Cidade de São Paulo).

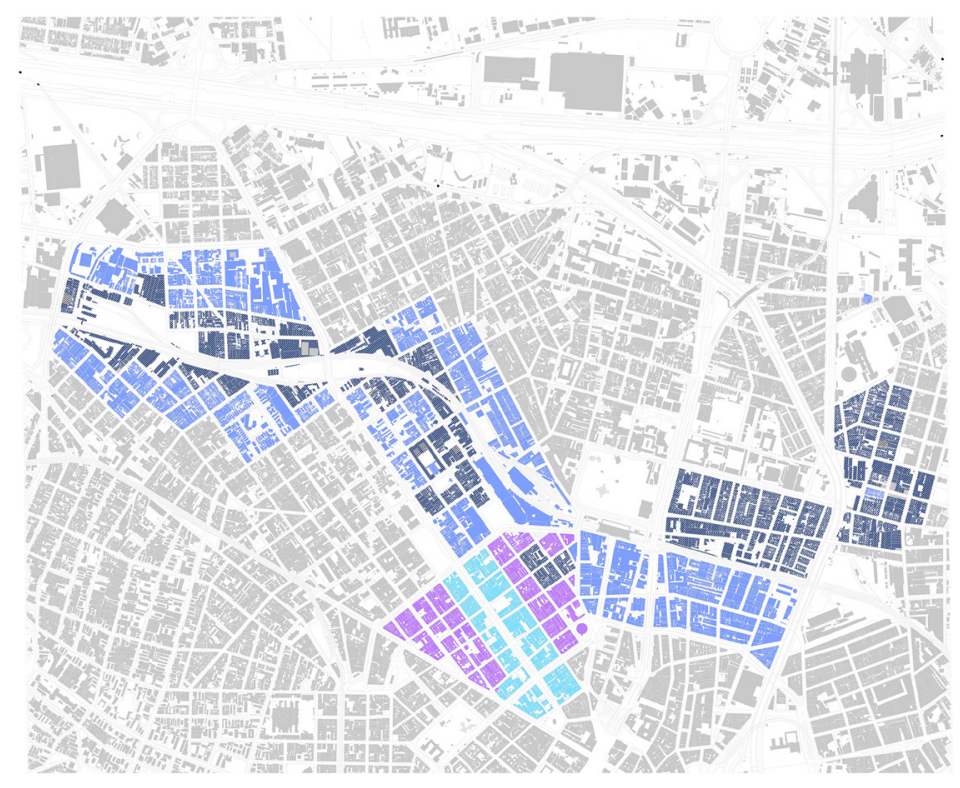

Elas formam um consórcio composto por agentes imobiliário (projetistas, construtoras, incorporadoras), agentes financeiros (bancos, fundos de pensão, ações, papéis de dívida) e Estado. Atuam através da renovação urbana (desconstrução, reconstrução, construção) e buscam captar rendimentos econômicos decorrentes do potencial construtivo adicional, acentuado pela diferença desta área com as demais regiões da metrópole, além da centralização da propriedade decorrente de desapropriações e demolições. Como expansão, entende-se a mercantilização de políticas e serviços públicos antes associados a políticas sociais. Neste sentido, a habitação de interesse social, equipamentos e serviços coletivos, espaços e infraestruturas públicos, passam a figurar como objetos de disputa pelo mercado.

Dentre esses planos do século XXI, analisou-se três experiências em função de sua semelhante estratégia e de relação com os marcos legais (jurídicos, financeiros e urbanísticos) que foram sendo constituídos ao longo dos últimos 20 anos.

O plano municipal Concessão Urbanística Nova Luz (2009-2012) é uma concorrência tipo técnica e preço, sob regime de execução por empreitada global e visa a contratação de empresa ou consórcio. Ela permite que o ente público relegue ao ente privado a realização de obras de urbanização, loteamento, demolição, construção e incorporação imobiliária nos perímetros definidos pelos planos específicos e que seguem as diretrizes regulamentadas pelo Plano Diretor Estratégico. Portanto, em tese, responde às exigências do interesse público, por meio dos planos e das respectivas leis e decretos que são definidos no exercício da atividade de planejador do Estado (executivo e legislativo). Para a realização destas obras, o consórcio privado é autorizado a fazer as desapropriações necessárias à implantação do plano, sob o argumento de que o "direito de utilização da propriedade fundiária", dispersa em inúmeros proprietários privados, não deveria "colidir com os interesses da coletividade". 
Níveis e dimensões da renovação urbana da Região da Luz: da experiência da espoliação à luta de classes socioespacial | 6

Mapa 8: NOVA LUZ_2012 (PETRELLA, 2017). Fonte: PETRELLA, 2017 (Elaboração do autor sobre base do MDC, Mapa Digital da Cidade de São Paulo).

Figura 1: NOVALUZ_2012. Superior: Volumetria, alturas e recuos do desenho urbano. Fonte: PUE, Nova Luz. Intermediária: Perspectivas da proposta arquitetônica e urbanística, espaços públicos e bulevares. Fonte: PUE, Nova Luz. Inferior: Perfis populacionais, residente e as novas demandas (pioneiros e seguidores). Fonte: PUE, Nova Luz.
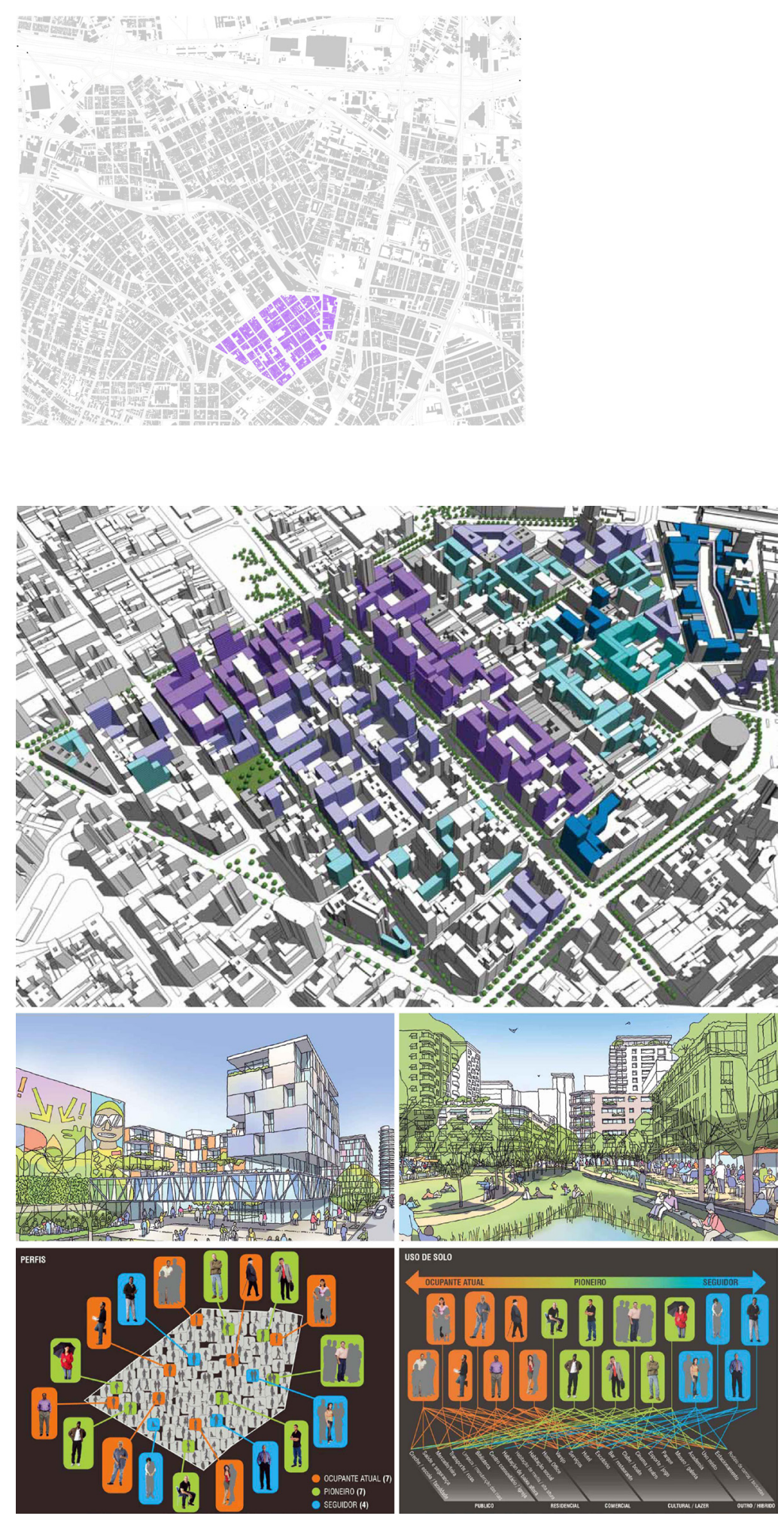
A PPP Casa Paulista (2014), desenvolvida pelo Governo do Estado de São Paulo, tem como objetos a concessão de projetos e de implantação de habitações de interesse social (reforma de imóveis existentes ou novas construções), de infraestruturas, equipamentos e serviços coletivos, bem como serviços de financiamento habitacional (nos parâmetros da His e Hmp), de gestão de carteira de mutuários, de administração condominial, de trabalho social de pré e pós ocupação. Portanto, a partir do aumento da oferta de habitações busca-se a "requalificação urbana" de espaços considerados como degradados e depreciados. As diretrizes arquitetônicas e urbanísticas se orientam por uma imagem de "cidade compacta", densa e associada à provisão de usos complementares à habitação: o uso misto e a mixité sociale. Busca-se, portanto, a partir do conjunto da intervenção, assegurar uma diversidade de formas edificadas que dão corpo a usos e grupos sociais diferenciados.

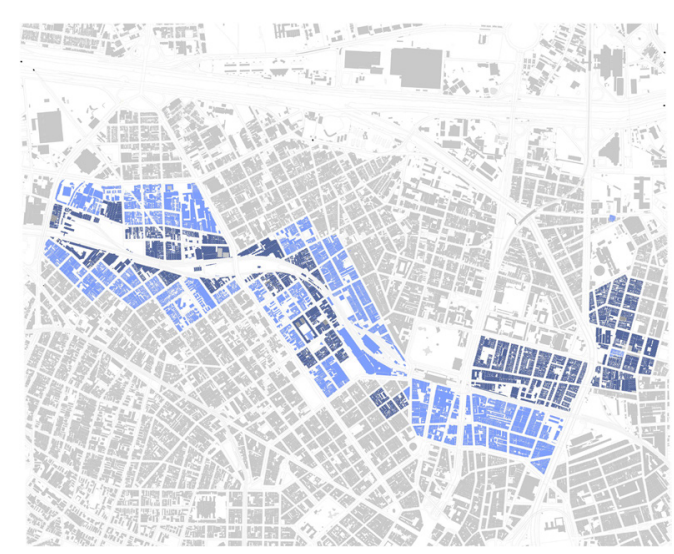

Mapa 9: PPP_2014. Fonte: PETRELLA, 2017 (Elaboração do autor sobre base do MDC, Mapa Digital da Cidade de São Paulo).

Figura 2: PPP_2014. Superior: Diretrizes arquitetônicas e urbanísticas que evitam as barreiras imobiliárias, edifícios isolados no lote e condomínio fechado. Fonte: Edital de Concorrência Internacional N. ${ }^{\circ} 001 / 2014$. Intermediário: Simulação do «desenho de cidade». Fonte: Urbem (https://www. urbem. org.br/casa-paulista) (acesso 25/01/2017). Inferior: Projeto de Biselli Katchborian para a PPP Casa Paulista na Luz, em frente à praça e estação Júlio Prestes. Fonte: <https://arcoweb.com.br/ noticias/arquitetura/ habitacao-e-cultura-na-luz-tera-projeto-de-biselli-katchborian>. Acesso 25/01/2017.
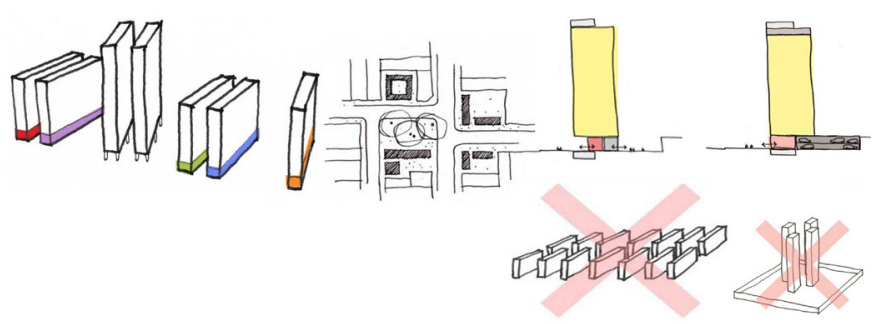
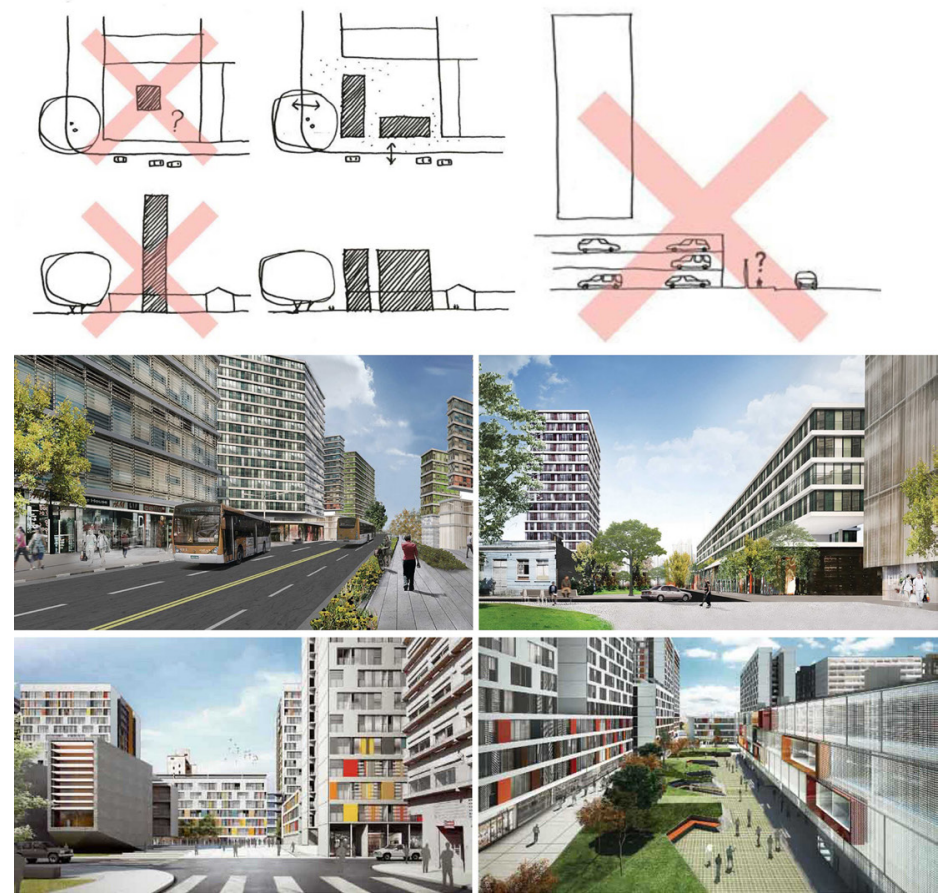
O Projeto de Intervenção Urbana PIU (2016), são estudos técnicos que buscam promover o "ordenamento e a reestruturação urbana em áreas subutilizadas e com potencial de transformação no Município de São Paulo". Busca associar projetos da Rede de Estruturação e Transformação Urbana em perímetros urbanos especiais, associados à Macroárea de Estruturação Metropolitana (MEM), a Rede Estrutural de Transporte Público, seus eixos. Visa estabelecer um programa de interesse público a partir das considerações expressas no Plano Diretor Estratégico, que deve ser realizado a partir da "diretriz urbanística, a viabilidade de transformação, o impacto ambiental ou de vizinhança esperado, a possibilidade de adensamento construtivo e populacional e o modo de gestão democrática da intervenção".

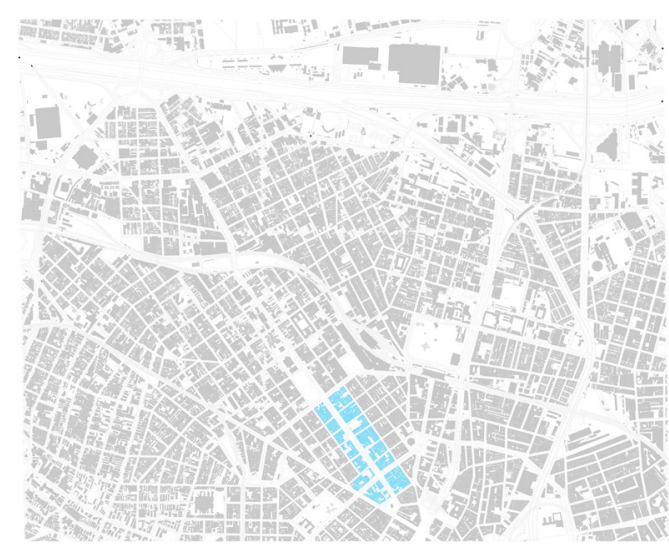

Mapa 10: PIU_2016. Fonte: PETRELLA, 2017 (Elaboração do autor sobre base do MDC, Mapa Digital da Cidade de São Paulo).

Figura 3: PIU_2016. Superior: Esquema de desapropriação para a implantação do PIU e incorporação imobiliária. Fonte: <http://cidadesparaquem. org /blog/2015/12/25/projetos-de-interveno-urbana-piu-so-paulo-inovando-na-interveno-pblica-sobre-o-espao-urbano>, acesso 25/01/2017. Inferior: Diretrizes arquitetônicas e urbanísticas de "requalificação e a reestruturação urbana em áreas subutilizadas e com potencial de transformação". Fonte: <http:// gestaourbana.prefeitura.sp.gov. br/noticias/prefeitura-de-sao-paulo-abre-consulta-publica-sobre-o-projeto-de-intervencao-urbana-piu-rio-branco/>, acesso 25/01/2017.

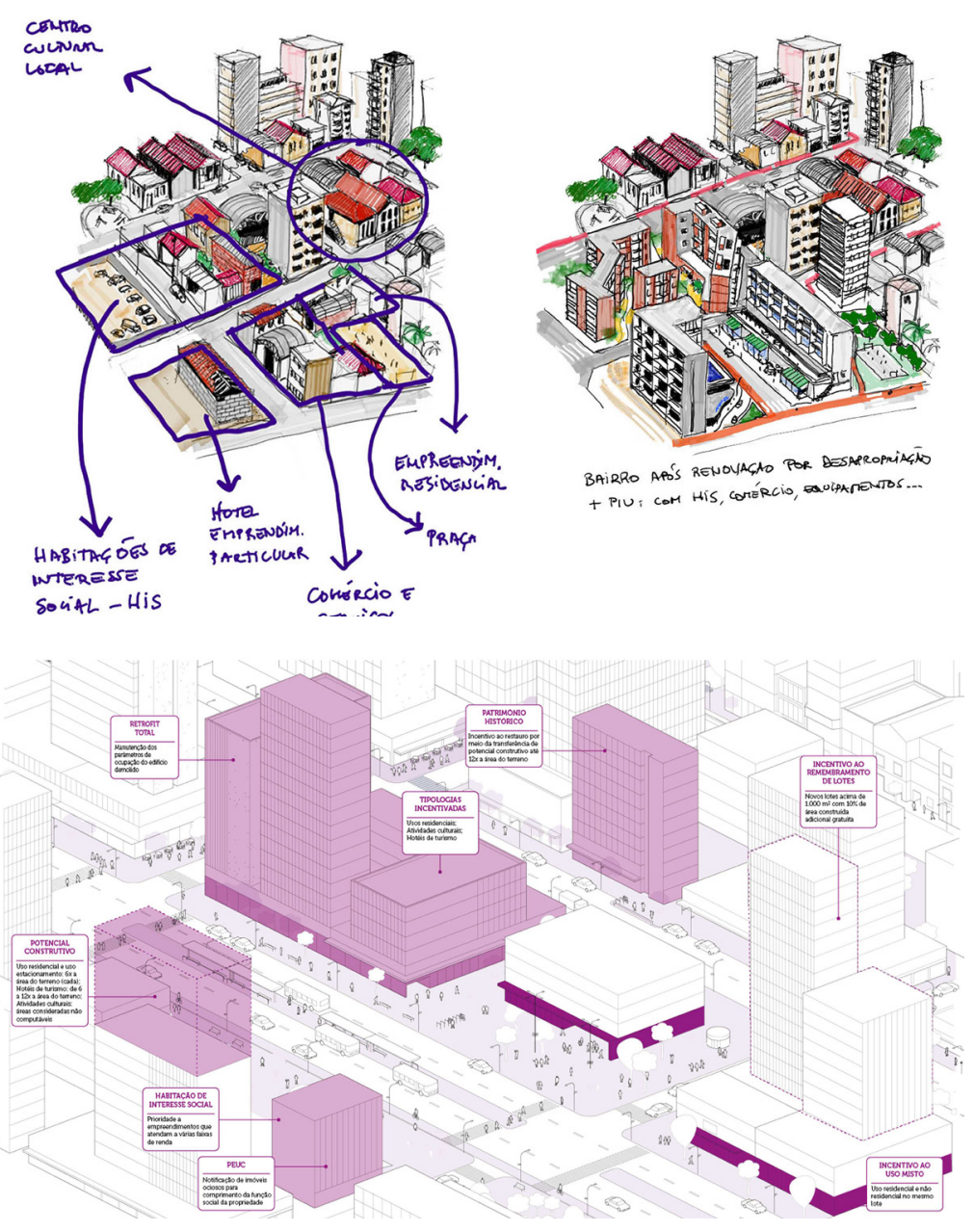


Esses planos urbanos aparecem inicialmente como o meio da reestruturação imobiliária e urbana e se lançam às estratégias arquitetônicas e urbanísticas de densidades, de conexões, de multiplicidade de usos, funções e formas. Diferenciações espaciais para diferenciações sociais: conjunto de estratégias, diretrizes e intensões que parece revelar um protagonismo desta forma de conhecimento, que orientaria o crescimento exponencial da construção, a reorganização da distribuição da propriedade, a própria cidade. Porém, pouco a pouco, a realidade desta aparência se manifesta como a capitalização da renda imobiliária, que decorre da monopolização da propriedade. A realidade dos planos é, portanto, assegurar uma viabilidade econômica do investimento público-privado na renovação urbana, e o "real" objeto da produção é a produção de propriedades imobiliárias, que passam a ser centralizadas através de cota-partes dos agentes dos consórcios. Seu instrumento é a construção do preço, mistificação e captura de fundos públicos, o excedente produzido socialmente.

Neste sentido, ao se deslocar o foco da produção para a propriedade, iluminamse conflitos e coalizões em torno da redistribuição do produto já produzido, nas políticas públicas e na produção do espaço: contradições que se revelam na ordem da propriedade e da apropriação. Em uma dimensão próxima, imediata, as condições ambientais atuais de degradação e abandono, uma relação socioespacial, um metabolismo urbano, articulam-se de um modo peculiar à espoliação do trabalhador, as respectivas formas de morar e de trabalhar. Por outro lado, a reestruturação imobiliária e urbana, trazida pela expansão desses planos, dão corpo, como uma manifestação local, ao complexo imobiliário financeiro de ordem global.

\section{Agentes em conflito na disputa pelo espaço}

A renovação urbana incide sobre práticas socioespaciais existentes, modificando-as, constituindo conflitos entre uma diversidade de agentes deste espaço. O primeiro agente a se iluminar é constituído em torno da coalizão do complexo imobiliário financeiro, de matriz global. Aqui são reunidos capitais privados que visam monopolizar tanto o potencial construtivo adicional quanto a propriedade privada centralizada na figura de um consórcio. Este processo se dá a partir da renovação urbana das áreas que apresentam a possibilidade de um crescimento exponencial da produção imobiliária, permitindo a privatização do valor socialmente produzido. Estes capitais são compostos pelos capitais operativos, cuja valorização dos investimentos se dá mediado por processos produtivos, tais como construtoras, empreiteiras e incorporadores imobiliários; e por capitais do financeiro, global e local, tais como investidores em ação, fundos de pensão, cartas de crédito, proprietários de papéis de dívidas públicas. Estes capitais são associados ao Estado, através de parcerias público-privada, que se materializam por meio de licitações, consórcios, contratos, sociedades de propósito específico (SPE).

O segundo agente a se iluminar é vinculado ao rentismo patrimonialista, que encontra na sua propriedade imobiliária um meio de acumulação de capital. Isso se dá pela exploração dos alugueis dos comércios e das habitações, corporificando a renda capitalizada em função da sua monopolização. Essas unidades imobiliárias estão por vezes subdivididas, deterioradas, decorrência de uma manutenção precária ou mesmo inexistente: baixo custo de (re)produção sem, contudo, causar prejuízos para a retenção da renda. Natureza própria do rentismo, da renda absoluta. Por outro 
lado, são estas as unidades que abrigam trabalhadores e moradores em suas diversas atividades cotidianas, onde são encontradas também diversas relações de trabalho e de moradia, mediados por contratos formais (de emprego, de locação, por exemplo), até a exacerbada informalidade das relações de uma "marginalidade" funcional à acumulação capitalista: trabalho informal, atravessadores, agiotas, subemprego, superexploração. Baixos salários em sua relação com o alto preço pago pelo uso de uma edificação inadequada, precária ou mesmo deteriorada. A conservação destas condições ambientais, portanto, como degradação física do patrimônio construído e como degradação física dos trabalhadores espoliados, é a condição de manutenção das relações econômicas, da acumulação através das rendas decorrentes dos alugueis. Uma especificidade metropolitana da região da Luz.

O terceiro agente a se iluminar é constituído por esse conjunto de trabalhadores e moradores, cuja existência e permanência no espaço passam a ser condicionadas pela realização da renda imobiliária, pagamento dos alugueis aos respectivos proprietários absolutos. O caráter espoliativo desta condição, o relativo alto preço pago, acentua a deterioração das condições de reprodução de sua vida: como reprodução da força de trabalho, como reprodução das relações de produção. Este agente sofre, de um lado, no uso dessas unidades imobiliárias deterioradas, a espoliação imobiliária, e, de outro, pela necessidade de salvaguardá-las para ali garantir sua existência e permanência, em função da rotatividade de trabalho e de moradia, por vezes aguçada pelas relações informais de contrato de trabalho e de habitação, cuja instabilidade e sujeição a poderes e micropoderes locais os obriga a deixar o espaço, acentuando a precarização das condições de reprodução de sua vida.

O quarto agente a se iluminar é o exército urbano de reserva, ou os sem-trabalho e os sem-teto. Estes agentes são identificados, reconhecidos, construídos ideologicamente, como se fossem o agente da degradação ambiental: ao mesmo tempo degradação do espaço (o patrimônio edificado) e da sociedade (o corpo). Seus corpos, "abjetos", e suas formas de apropriação do espaço, instigam processos sociais de reversão da deterioração ambiental, fomentando políticas públicas, planos urbanos, ideologias, intervenções técnicas e tecnocráticas: constituem práticas sociais. São a expressão de despossessão total e usam o espaço sem a mediação direta da propriedade privada (a não ser em função de sua exclusão causada pela propriedade).

\section{Níveis e dimensões de análise}

${ }^{1}$ Cf. Petrella, 2017; Pereira (org.), 2018.
A análise desses planos, por outro lado, dialoga com um conjunto de pesquisas ${ }^{1}$ que analisa processos imediatos de reestruturação do espaço metropolitano, a partir da produção imobiliária, da provisão de infraestruturas e da generalização da forma da renovação urbana. Busca compreender a especificidade de cada situação (arquitetônica, urbanística, política, econômica e ideológica) e relacioná-las a reestruturação da metrópole como um todo, compondo um conjunto diferenciado na e da urbanização. Porém, nesta diferenciação há a realização de estratégias que são comuns (ainda que suas formas de manifestação possam ser distinguíveis). Elas também podem ser observadas em outros contextos regionais e nacionais, o que torna mais complexo o entendimento da relação entre as especificidades locais da renovação urbana e as formas globais de sua realização. 
O nível imediato, por sua vez, relaciona-se ao global, vinculado à reestruturação institucional do Estado e das políticas públicas a partir da intensificação da agenda do neoliberalismo, que vai estender, entre outros, a instrumentalização da produção do espaço como meio econômico de absorção do excedente financeiro. Isso promove sua reprodução ampliada a partir da especificidade espacial da acumulação capitalista. Aqui, a capitalização da renda, representada pelo título de propriedade, tanto imobiliária quanto financeira, estrutura a instrumentalização. A propriedade se constitui como estrutura desta forma de urbanização e permite a privatização da riqueza social através da construção arbitrária do preço do produto imobiliário (Petrella, 2020), associada ao endividamento (público e privado), fontes de rendimento. Isso se relaciona à coalizão de classes e suas frações que têm na propriedade seu meio de existência. Elas se tornam hegemônicas no domínio sobre o Estado, sobre as políticas públicas e sobre a riqueza socialmente produzida pelo trabalho e sua distribuição. Isso se manifesta no predomínio das formas de acumulação por espoliação, intensificadas na produção do espaço, acentuando a precarização na reprodução da vida.

Por fim, como aproximação ao nível da totalidade (Lefebvre, 1999; Pereira (org.), 2018) a análise busca dar ênfase na reprodução social, que está cada vez mais submetida aos imperativos político econômicos intensificados pelo neoliberalismo e pela financeirização. Político no sentido que remete a um domínio de classe, as classes proprietárias de capital e de terra; econômico na medida que sua reprodução depende da espoliação do cidadão em geral, baseada no predomínio da renda capitalizada. Portanto, uma estrutura que dinamiza a apropriação privada do comum, assegurada por novas regulamentações imobiliária e financeira estatal, implicando na reestruturação dos planos urbanísticos de renovação urbana. Esta nova estrutura interage com as formas sociais que se já realizam nesses territórios, produzindo, por decorrência, outras formas de resistência e de luta contra isso. Movimento que explicita conflitos socioespaciais a partir da renovação urbana: processos espoliativos (imobiliários, urbanos e financeiros) que agem sobre indivíduos e coletivos (corpos); e a renda capitalizada como meio predominante de acumulação, operando um desvio teórico-prático da produção estrita (visão fabril) para o espaço como totalidade da reprodução social. Aqui, a renda, em suas diferentes formas (extrativista, fundiária, patentes, saberes, imobiliária), articula acumulação de capital e domínio de classe.

Neste sentido, "movimentos sociais" passam a (poder) ser (re)orientados por um problema socioespacial contemporâneo, uma nova subjetividade constituída no interior da disputa pelo uso e pelo valor do espaço, que deve ser experimentado, reconhecido e interpretado na totalidade do cotidiano e da reprodução. Totalidade da vida que deve ter lugar, fala, ação e representação. Constitui uma experiência de «luta de classes sem classe» (Thompson, 1979; Wood, 1983), na qual esses agentes podem se reestruturar e emergir como um outro sujeito político e histórico, emersão decorrente da experiência cotidiana de viver a metrópole. Portanto, hipoteticamente, a experiência e o reconhecimento da resistência social a processos espoliativos de reprodução do capital pode constituir virtualmente uma luta de classes, socioespacial, que se orienta praticamente à constituição do «direito à cidade», direito constituído pela resistência e pela produção do novo.

A reestruturação imobiliária e urbana da metrópole paulista é um processo social amplo, que envolve dimensões políticas, econômicas, ideológicas que se combinam 
e estão em movimento (cf. Pereira (org.), 2016, 2017, 2018). Parte deste conjunto de transformações pode ser avaliado a partir da particularidade da arquitetura e do urbanismo como um campo de conhecimento que emerge desta dimensão imobiliária e urbana na produção do espaço. Esta especificidade ilumina uma forma de articulação de níveis e dimensões de análise (Lefebvre, 1999). Nos termos do imediato, situam-se as relações de trabalho, de produção (de coisas no espaço e do espaço em si, como relações sociais) e de produto, que se realizam a partir de condições e determinações locais. Elas se articulam a uma dimensão global, relacionada a processos político, econômico e ideológicos de reprodução mais amplos, que se situam para além desta produção imediata estrita, em uma dinâmica que extrapola seus limites e fronteiras. Por sua vez, essa articulação constitui uma experiência específica, de um tempo histórico determinado. Formas de produção e reprodução social. Isso constitui a totalidade do contemporâneo, a ser elucidada pelo constante movimento de reflexão crítica, teórica e prática.

Os planos de renovação urbana podem ser avaliados a partir do imbricamento desses níveis e dimensões de análise. Eles se estruturam a partir de parcerias público privada, que articula Estado (leis, financiamentos, planos e políticas públicas e sociais), agentes produtores (construtores, projetistas, trabalhos) e agentes financeiros (bancos, fundos de pensão e de investimento). Cada plano em particular constitui uma Sociedade de Propósito específico (SPE), um contrato entre parceiros público e privado específico para o plano urbanístico e cujo domínio é relativo ao aporte de recursos financeiros de cada um dos respectivos agentes: equivalente a uma «cota-parte condominial», a «sociedade por ações». A finalidade do plano é assegurar a viabilidade econômica do conjunto de investimentos e de empreendimentos, que se distribuem em habitação de interesse social, equipamentos coletivos, espaços públicos, infraestrutura e serviços. Esta viabilidade define o tipo de produto, as formas de produção, a demanda social a ser satisfeita e as formas de financiamento e crédito para produção e consumo.

Ela é modelada a partir da pressuposição da valorização e da capitalização que devem ser realizadas após a reestruturação do espaço como um todo. Pressuposição que decorre da expectativa a priori de «valorização e apreciação» da região em relação à diferença de ofertas imobiliárias no todo da metrópole, constituindo-se (virtualmente) uma especificidade local. Essa expectativa reduz o alcance das políticas públicas e das formas urbanas do espaço, seus diversos e possíveis usos, à lógica privada de retorno financeiro, que ganha corpo a partir da valorização imobiliária. Ela é estruturada para ser privatizada nestas operações urbanas a partir da monopolização da propriedade imobiliária e financeira, que pertencem aos agentes deste contrato, dado que seu custo deve ser reposto ao final da operação com um acréscimo equivalente a qualquer investimento financeiro: o preço da propriedade se constitui pela apropriação do excedente, embora não tenha contribuído como força produtiva. É neste sentido que subordina as formas de produção e de consumo do espaço, retirando dele a pressuposição de valorização e de capitalização, além de intervir no metabolismo social destes territórios.

Por outro lado, estas parcerias público-privada incorporam capitais que circulam nos circuitos financeiros de composição global e que se aproximam dos planos a partir dos recursos centralizados nos agentes destes consórcios: abertura de capitais das empresas construtoras nas bolsas de valores, fundos de pensão de empresas nacionais e internacionais que aí investem, papeis de dívida pública. Este excedente 
fictício que "cria valor sem produzir valor», circula ao redor do globo na busca de plataformas imobiliárias e financeiras de valorização (Paulani, 2008), absorvendo o excedente (Harvey, 2011) e o reproduzindo de modo ampliado através da produção do espaço (Petrella, 2017). Esta composição financeira global define ritmos e formas de produção por onde aterrissam momentaneamente, assim como seus produtos, demandas sociais que realizam o investimento e as políticas públicas. Neste sentido, a presença do Estado nestas situações é imprescindível, seja pela reestruturação dos marcos legais imobiliários e financeiros, que se aproximam nesta reestruturação, seja pela reestruturação das políticas públicas com expressão urbana. Portanto, caracteriza a intensificação do avanço neolibera/que acentua a presença do Estado, mas de uma presença que é instrumentalizada para a privatização da produção social.

Neste sentido, a experiência contemporânea da urbanização se distingue daquela realizada predominantemente no século $\mathrm{XX}$, que combinava a produção extensiva na periferia, realizada como ausência do Estado na provisão de habitação, de equipamentos e serviços públicos coletivos; com a intensificação e verticalização em outras regiões da metrópole, como presença do Estado na provisão desses equipamentos e serviços públicos (Pereira, 1988). Na "ausência periférica», as condições gerais de reprodução da força de trabalho e da vida são supridas pelo trabalho dos próprios trabalhadores. Isso foi interpretado como a forma urbana predominante na acumulação capitalista industrial no Brasil: na medida em que estes territórios são construídos pela obstinada produção doméstica dos próprios trabalhadores, os custos equivalentes à esta produção, constituintes da cesta de consumo da reprodução da força de trabalho, eram retirados dos salários e, portanto, proporcionavam o aumento do lucro industrial sem um incremento proporcional de força produtiva, acentuando a exploração da força de trabalho e a espoliação do cidadão (Oliveira, 2003).

Nesta situação, a organização social em torno de «movimentos» buscava reivindicar a presença do Estado, a provisão de habitação, equipamentos, infraestrutura e serviço públicos. Portanto, lutas sociais que se estendiam do chão da fábrica ao chão da cidade, elucidando o papel da urbanização na acumulação capitalista não só como resultado da acumulação tipicamente industrial, mas concebendo a produção do espaço como um seu elemento propulsor: a reprodução das relações de produção (Kowarick, 1993; Sader, 1988). No conjunto da metrópole acentuava-se a diferenciação espacial e em relação à desigualdade social, combinando-as.

Ainda que essa produção doméstica da periferia persista na atualidade, decrescente se comparado ao crescente acesso à moradia por meio do aluguel, não pode mais ser interpretada a partir da dualidade ausência-presença do Estado: sua onipresença diferenciada se realiza nos diversos territórios e reitera as formas diferenciais de produção do espaço e desigualdades sociais (Petrella, 2018). O Estado age de modo diferenciado e de acordo com cada uma das situações e reinvindicações. Em paralelo, nem mesmo a dualidade centro-periferia tem força explicativa. As diferenciações espaciais e desigualdades sociais estendem-se e se intensificam, combinando-se ao nível da reprodução social. O que se ilumina neste momento é que as especificidades de cada uma das situações são apropriadas de modo diferenciado nesta totalidade. Neste movimento é que se inserem as renovações urbanas do século XXI: a onipresença do Estado e a ocupação popular da área central. Toda a sorte de trabalhos e moradias informais ou irregulares, que constituem uma periferização do centro. 
Isso nos traz um problema político, à luz da constituição de movimentos sociais urbanos. Constatamos que a provisão pública se realiza como instrumento de apropriação privada a partir das parcerias e pela ênfase posta na propriedade imobiliária e financeira (Petrella, 2017): a reprodução a partir da renda capitalizada. Portanto, aquela experiência política de reinvindicação da presença do Estado, como presença das políticas públicas setoriais (habitação, saúde, educação e etc.), hoje pode ser interpretada como agente da intensificação da exploração do trabalhador e da espoliação do cidadão. Condição exposta pela hegemonia da economia política neoliberal e financeira. Estas provisões contribuem com o aumento de preço de terrenos, de edifícios e de alugueis, precarizando a reprodução da vida. Além de não se adaptar às reais demandas sociais, presentes nestes espaços e ausentes destas políticas públicas (e privadas). Neste caso, esta forma de provisão reproduz a diferenciação e a desigualdade de princípio (da forma de distribuição do produto social na e da metrópole), além de permitir benefícios e vantagens particulares no interior da diferenciação, recolocando as disputas e os conflitos, inclusive, no interior da classe trabalhadora: ao reivindicar uma parcela diferenciada da diferenciação sem negar a valorização imobiliária, em si diferenciada, naturaliza-se a desigualdade socioespacial de origem e a decorrente. Assim, a luta por direitos setoriais (direito à moradia, direito à saúde, direito à educação e etc.), em suma, como «direitos na cidade» realizados pelos empreendimentos das renovações urbanas, apesar de necessário não se mostram suficientes para reverter o processo histórico de intensificação da exploração do trabalhador e de espoliação do cidadão. Não contém o processo de valorização imobiliária e o monopólio da propriedade como meio de propulsão da privatização da riqueza socialmente produzida, do comum.

Isso ganha corpo a partir da própria reestruturação institucional do Estado, dominado por classes patrimonialistas (i)mobiliárias, que exacerba sua instrumentalização, orientando-o para o predomínio das formas de acumulação que beneficiam este poder político e econômico parcial, da propriedade. Este «Estado-instrumento», fruto do avanço do neoliberalismo, da financeirização e da hegemonia de uma nova coalização de classes, reestrutura políticas públicas, marcos legais, sistemas repressivos em favor da coalizão. A presença do Estado nestes termos significa, portanto, a presença de formas de acumulação desigual da riqueza socialmente constituída. Nesta produção imobiliária e urbana a produção para mercado tende a predominar sobre as demais formas de produção. Tende a dominar e subordinar a produção estatal e a produção doméstica, que se aproximam sob este domínio: obras públicas (acentuadamente privadas pelas parcerias) que são destinadas à população que acessa o urbano por relações domésticas de produção (e de consumo), passam a ser (re)orientadas pela lógica de reprodução relacionada à viabilidade econômica, proposta (e pressuposta) pelo mercado. Estado e mercado agem afinados pelos mesmos princípios.

Neste sentido, a noção de espoliação urbana (Kowarick, 1993), caracterizada em sua origem como a espoliação do cidadão que não tem seu direito assegurado em função da ausência do Estado, deve ser reinterpretada na medida em que a espoliação se intensifica com a presença do Estado. Ela se desdobra em duas outras noções que se exacerbam na atualidade: a de espoliação imobiliária e a de espoliação financeira. Embora diferentes, apresentam-se como a unidade predominante na atual forma de produção do espaço, no imbricamento entre a incorporação e a infraestrutura sob lógica imobiliária e financeira. 
2 Juros é um dinheiro que se amplia ao ser investido em um processo produtivo. Aquele que «empresta» esse montante, recebe-o ao final do prazo pré-estabelecido com um acréscimo: os juros. Já no caso da renda - e é por este motivo que os juros estão anotados aqui entre aspas - o retorno financeiro não decorre de uma produção, mas sim da «permissão» de uso de um bem monopolizado na forma da propriedade. Deste modo assegura-se um retorno financeiro sem a contrapartida de um processo real de produção de valor. Este acréscimo, portanto, que não vem de uma produção em particular, decorre da privatização de um valor socialmente constituído, relegando, deste modo, a toda a sociedade $\mathrm{o}$ "peso da renda $\mathrm{e}$ da propriedade», que beneficia apenas alguns.
A espoliação imobiliária decorre da centralização da propriedade, que permite a acumulação de capital no que tange à formação da renda imobiliária (aumento de preço dos terrenos, de edifícios e do aluguel). Neste caso há acúmulo de capital mesmo sem a presença de uma nova produção, sem um novo processo de valorização. E quando há, o custo referente ao acesso à propriedade, seu preço, deve ser reposto ao final da produção acumulando «juros»» ${ }^{2}$, tal e qual qualquer investimento financeiro. É uma acumulação que ao não produzir mais valor, privatiza o excedente de valor que é socialmente produzido. A espoliação financeira também não se define pela ausência de recursos financeiros ou do Estado, mas sim pela presença assediante de créditos e de formas de financiamentos que expandem seu campo de ação pelo endividamento. Figura-se como meio de dilapidação das condições de reprodução da força de trabalho (a longos períodos, relativo ao prazo da dívida) e como a expansão das fronteiras de capitalização para zonas antes não tomadas pelo financeiro, tais como os serviços públicos (saneamento, energia, habitação, etc.) que se privatizam. O mercado de crédito fornece produtos financeiros no lugar das políticas do Estado, aparecendo e realizando-se como serviços.

Estas duas dimensões da espoliação aproximadas se realizam nas renovações urbanas. Elas permitem que a «ficção» da capitalização da renda (i)mobiliária encontre um «lastro real» na produção do espaço, que absorve (Harvey, 2011) e capitaliza o excedente (Petrella, 2017). Além de estender as fronteiras (infernais) da acumulação pela incorporação de territórios e tecidos urbanos «marginais» (Kowarick, 1977), deteriorados e obsoletos à luz da diferenciação da metrópole. Nestes casos, o potencial de construção adicional permitido excepcionalmente pelos planos (concentração de forças de produção) identifica-se ao potencial de renda imobiliária que decorre da reestruturação da distribuição dos terrenos e edifícios (centralização de forças de propriedade), elevando-se se comparado à renda imobiliária já realizada nas condições atuais. Constitui um aumento de diferencial de renda, um rent gap (Smith, 2007, 2015) cuja diferença se figura como o limite da pressuposição da valorização e da capitalização dos investimentos financeiros a serem realizados na renovação. Este rent gap engendra o encarecimento das condições gerais de reprodução da vida, interferindo no metabolismo socioespacial existente (moradia, trabalho, serviços), expulsando eventualmente a população originária: um processo de gentrification (Idem, ibidem). A reprodução do capital, portanto, se realiza às custas da precarização das condições de vida, somando exploração e espoliação.

Esta produção mercantil intensifica a marcha de mercantilização do espaço, que se desdobra das estratégias privadas de produção de condomínios fechados privados (Tone, 2010) para o domínio de produção e propriedade em perímetros urbanos públicos da metrópole (definidos pelos planos de renovação urbana). Busca estender o domínio sobre uma morfologia urbana e suas relações sociais de produção e de consumo intensificando a noção de «enclave antiurbano» no interior do «urbano». Contudo, esta marcha da mercantilização encontra (e produz) uma contramarcha de resistência, fazendo-se necessário reconhecer as relações socioespaciais que experimentam e eventualmente escapam a esta marcha. Elas se figuram como a precariedade que é agravada pela desigualdade social, dado que parcelas da população se invisibilizam nestas políticas público-privadas (estão à «margem» das pressuposições de realização dos planos), como também que se ilumina o ainda não-incorporado por esta reprodução capitalista mercantil (situadas como eventuais fronteiras de expansão). 
Constitui, portanto, um duplo-sentido do residual (Lefebvre, 1999): tanto como sobra como o não-iluminado (campo cego) pelo pensamento crítico. Ambos constituídos como subprodutos da marcha da mercantilização.

O resíduo aparece, portanto, como a contradição entre o possível-impossível da luta social na especificidade espacial da produção e reprodução capitalista. No resíduo, novos campos de luta. Inicialmente como resistência (negação), posteriormente como projeto (negação da negação, superação positiva). Neste sentido, a questão que se coloca é como a experiência da espoliação pode constituir formas de resistência social e na experiência desta resistência como ela pode constituir uma consciência de classe. É evidente que esta «classe» não pode ser mais interpretada aos moldes da classe trabalhadora operária fabril. Ainda que se desdobre desta concepção, a experiência cotidiana de resistência a espoliação na metrópole deve incorporar a totalidade de formas de concepção de vida, outras subjetividades constituintes da experiência dos sujeitos políticos. Como possibilidade, a constituição de uma unidade-diferenciada do trabalhador-cidadão, enquanto classe socioespacial constituída contra a expansão da mercantilização que inviabiliza a reprodução plena da vida. Esta mercantilização é a combinação entre capital e terra (Marx, 19851986, L.III, V.5, 269, 317), que dominam as relações de trabalho e disputam entre si o predomínio das formas de acumulação. Capitale terra estão em contradição e nela as fissuras devem ser abertas pela luta do trabalho. Mas esta luta ainda deve se constituir como unidade reconhecida dos trabalhadores. Como luta de classes que se estende à totalidade da vida, ao espaço da reprodução social. O sentido da experiência.

\section{O sentido da experiência: resistência à espoliação}

Como visto, a acumulação por espoliação se diferencia da forma tradicional de entendimento da acumulação por exploração (embora permaneçam em relação). Como exploração, são as relações de trabalho e de produção a essência para seu esclarecimento. As formas econômicas de lucro e juros são suas manifestações. Como espoliação, são as relações de propriedade que as definem. Propriedade de terra e de capital. O custo pago para utilizá-las, para produzir ou para reproduzir enquanto uso e consumo, não correspondem a uma produção direta de valor, a um processo produtivo. O preço de uso de um monopólio que constitui uma renda. Isso vem de encontro com as análises sobre o capitalismo contemporâneo que têm apontado ao predomínio das formas de renda na acumulação capitalista (Chesnais, 2005; Piketty, 2014; Harvey, 2016, 2018), relativas ao monopólio de um espaço ou de um capital.

Em relação ao espaço, as rendas se diferenciam em função do uso concreto, tal como a renda extrativista e a renda fundiária que se beneficiam da materialidade deste espaço, a «fecundidade» da terra e seus elementos dela retirados; ou, por outro lado, do uso abstrato, restrito ao perímetro espacial utilizado como base para uma (re)produção, tal como a renda imobiliária. Neste caso, o título de propriedade adquire um preço, uma equivalência de valor (embora não tenha valor por não ser produto de trabalho) que deve ser reposto ao final sem ter sido força produtiva. Em todas essas formas de renda elas se articulam a circuitos financeiros, cujos excedentes são criados mediante uma produção (o capital portador de juros) ou simplesmente pelo uso e troca de propriedades financeiras, que geram «mais valor sem produzir valor»: títulos de ações, papéis de dívida, troca de moedas. Excedentes financeiros que são criados descolados de qualquer produção imediata, intrínseco à sua circulação. 
Isso nos coloca um problema da reprodução socia/ na medida em que a pressuposição de valorização e capitalização particulares condicionam, subordinam e submetem relações sociais amplas de reprodução da vida (corpo e ambiente). Por oposição deve se constituir, virtualmente, um espaço do devir: oposição comum à extensão das fronteiras infernais de acumulação capitalista, que se estendem e se intensificam em detrimento da reprodução da vida. Deste modo, a presente presença do Estado e do mercado unidos, pode ser interpretada como uma «presença-avessa», cuja instrumentalização para a reprodução do capital, que descarta o excedente que é «impróprio» para a acumulação, constitui a necessidade de resistência.

Neste particular, as formas predominantes de acumulação capitalista se dão pela dimensão fictícia de valor sendo a produção do espaço uma condição necessária de absorção e capitalização do excedente. Deste modo, o pensamento crítico deve buscar reconhecer novas práticas sociais e seus sujeitos, que permitam a imposição de barreiras à reprodução do capital, bem como a insurgência de um (novo) projeto para a constituição do devir. Um sujeito político, posto em cena à luz da experiência da luta de classes (Thompson, 1979; Wood, 1983), que ainda forja a consciência de si como classe, apesar de experimentar cotidianamente processos dilapidadores da espoliação. Neste sentido, a experiência cotidiana e espacial de resistência à espoliação, pode se figurar como momento da «tomada de consciência», como prática e crítica à subordinação da reprodução da vida. Uma experiência que se orienta para a constituição da unidade do «sujeito socioespacial» como classe. Paralelamente, isso inclui a crítica e a superação de ilusões que reproduzem teorias e práticas funcionais à reprodução capitalista: lutas sociais orientadas pela reinvindicação de políticas setoriais, de aquisição de «direitos na cidade» experimentada predominantemente no século XX. Estas práticas, embora necessárias, são tomadas pela reprodução do capital, tonando-se insuficientes.

Qual seria o objetivo? Construir o poder do trabalhador-cidadão enquanto classe. Reconhecer na experiência de resistência à espoliação a unidade-diferenciada da classe trabalhadora, classe socioespacial a se constituir. Como objeto e condição pode iluminar a dimensão da injustiça espacial, que abre frente à luta por justiça. Esta experiência pode proporcionar a angústia, a revolta, o protesto e a ação. Não só por direitos na cidade, mas pela própria constituição do direito à cidade (Lefebvre, 1981). Tudo no campo determinado da resistência à marcha da mercantilização, uma negação determinada, com vias de uma superação positiva, a constituição de um projeto próprio, autônomo, criativo.

O momento do auto reconhecer-se como trabalhador-injustiçado perante o sistema dominante deve superar o ponto cego do espaço como lugar da reprodução social e sua experiência. Se as lutas operárias típicas do século XX centralizavam seus esforços na fábrica e no campo, como protagonistas da história, hoje esta experiência se torna insuficiente. O foco na indústria fabril obscurece a dinâmica própria da especificidade espacial, a absorção do excedente econômico e sua reprodução por meio da propriedade e da renda (em suas diferentes formas). Este protagonismo se desarticula na medida em que a precarização contemporânea do trabalho reduz a possibilidade de sublevação do trabalhador pelas vias tradicionais dos sindicatos e movimentos campesinos, pois estes perdem tanto sua legitimidade de representação quanto, o que é pior, seu poder e eficiência face à estruturação do capitalismo contemporâneo, neoliberal e financeiro. Isso significa que outros meios criativos de organização dos trabalhadores devem vir à superfície. Emersão teórica de uma prática já experimentada em seu germe. 
O auto reconhecer-se enquanto trabalhador nasce de uma experiência, por exemplo, contra o aumento do preço das condições de reprodução da vida (serviços urbanos como saneamento, água, energia, espaços e serviços públicos). Apreciação que se realiza com a finalidade de financiar as pressuposições e expectativas de retorno financeiro (capitalização) das empresas privadas que os administram ou dominam (à luz das privatizações, concessões e parcerias). Mas, não se restringe a isso, dado que o preço pago acima dos benefícios imediatos que representam se estende a uma diversidade de serviços e bens de consumo. Portanto, o «reconhecer-se» inclui noções de comunidade e vizinhança, práticas de solidariedade, na medida em que a experiência cotidiana da espoliação se realiza em territórios e populações localizados no interior da metrópole diferenciada, não apenas no indivíduo. Um reconhecimento de sique passa pelo reconhecimento do outro, o «inimigo comum» que se apresenta, como um fenômeno, a partir da ação do Estado-presente-avesso.

Neste sentido, a ação crítica, teórica e prática, deve contribuir para estender os «direitos na cidade» para a constituição do direito à cidade como totalidade. E a diferença entre estas expressões se dá sob ótica da valorização imobiliária: enquanto o acesso ao direito permanecer mediado pela propriedade, a espoliação imobiliária ou financeira, não há a possibilidade de sua superação. Por outro lado, o inimigo comum não se resume às práticas do Estado-presente-avesso. Relaciona-se a poderes e organizações «paralelos»: o crime organizado, novas formas de sociabilidade religiosa e organizações não-governamentais, intensamente experimentadas. Eles se colocam como uma capa mediadora da tomada de consciência da classe social, velando seus benefícios econômicos particulares e subordina populações através de seus respectivos meios de subjetivação, mas também, de poder e de violência.

A empreitada do auto reconhecer-se inclui concepções de vida e identidades que se manifestam na reprodução social e no cotidiano. A classe, não pode ser mais resumida e reduzida ao seu papel no interior da produção fabril, que abstrai especificidades em função da própria natureza abstrata do trabalho. Na virtual constituição da classe socioespacial, uma experiência que se funda na diversificação das formas de reprodução da vida, incluem diversidades e identidades distintas. Sua formação deve partir do reconhecimento destas diferenças. A negligência dessas questões apenas exacerba a desunião e a desconfiança entre seus agentes: o reconhecere o pertencer da «classe trabalhadora» estão condicionados pela aceitação integra/ do sujeito que reconhece seu pertencimento: subjetividade, laços sociais, relações, práticas e formas de felicidade. Concepções de vida constitutivas da unidade-diferenciada-assim como a produção do espaço - na medida em que a experiência do vivido, do trabalho ao não-trabalho, inclui a totalidade da vida e expande as condições reconhecimento e de pertencimento como seres humanos completos.

O grande entrave é a cultura da mercadoria que medeia e opera o desvio do cidadão (espoliado) para a noção de consumidor (empreendedor). Desvio que se realiza no entendimento de que o acesso a direitos se dá por meio do consumo de bens e de serviços, que vai se manifestar, também, como o consumo do próprio espaço. A centralidade do consumidor (que inclui a experiência prática do «não-consumidor», como nos diz a boa dialética), proporciona a experiência de falta e frustração. Pulsões individuais e subjetivas que obscurecem a (ir)racionalidade do sistema de reprodução capitalista como um todo, fictícia e excludente. Ilumina-se a necessidade de converter 
as «pulsões individuais» em unidade-diferenciada da luta dos trabalhadores. Uma luta comum: a retomada da noção de cidadania pelo direito à cidade, em detrimento das pulsões de consumo.

A cultura da mercadoria, a mercantilização do espaço, expressa o avanço do domínio objetivo e subjetivo do capital sobre o trabalho. O trabalhador-cidadão passa a se reconhecer como investidor, pequeno proprietário, empreendedor, estruturando sua ação cotidiana a partir do cálculo e dos rendimentos econômicos (Martins, 2000). Deste modo a consciência de classe permanece enfeitiçada sob o fetiche da alienação, que decorre de práticas reais (acesso à direitos através do consumo, capitalização permitida pela propriedade), mas não verdadeiras. Isso tem implicações na produção social do espaço: a construção de necessidades e desejos que são funcionais à reprodução do capital e não necessariamente à reprodução integral da vida, em toda a sua potência diferenciada, a produção humanamente adequada (Lefebvre, 1971). Essa capa mistificadora enfraquece as noções de história e de coletividade (produção social), como prática reduzida a emblemas de compra e venda de bens e direitos (inclusive aqueles de origem estatal).

Assim, as ideias e as práticas precisam se tornar perigosas novamente. Não basta colar nos movimentos sociais e suas práticas correntes, mas buscar elucidar a contradição para instruir o movimento sob a perspectiva da mudança radical: não reformista, mas revolucionária. Esta condição pode ser acessada não pela garantia de direitos na cidade, mas pela própria constituição do direito à cidade através da desmercantilização do espaço e da vida, renda e endividamento, cuja experiência cotidiana, de resistência e de projeto, possa pôr em xeque a estrutura de reprodução do capital. Como ela está condicionada pelos processos espoliativos, renda e acumulação fictícia, a negação da natureza da propriedade deve ser empreendida praticamente: as conexões e fissuras entre as dinâmicas imobiliárias e financeiras, à luz do Estado neoliberal e financeiro, além da hegemonia da classe proprietária. Ao lado, do reconhecimento da unidade-diferenciada do trabalhador em sua re-produção integral, que traz à luz a experiência espacial. Contra a submissão da reprodução da vida à cultura mercantil da reprodução do capital.

Espoliados do mundo, uni-vos!

\section{Referências bibliográficas}

CHESNAIS, François (org.). A finança mundializada. São Paulo: Boitempo, 2005.

HARVEY, David. O enigma do Capital e as crises do Capitalismo. São Paulo: Boitempo, 2011. 17 contradições e o fim do capitalismo. São Paulo: Boitempo, 2016. 2018.

KOWARICK, Lúcio. Capitalismo e marginalidade na América Latina. Rio de Janeiro: Paz e Terra, 1977.

A espoliação Urbana. Rio de Janeiro: Paz e Terra, 1993.

LEFEBVRE, Henri. El materialismo dialectico. Buenos Aires: Pleyade, 1971. O direito à cidade. São Paulo: Moraes, 1981 . 
LEFEBVRE, Henri. A revolução urbana. Belo Horizonte: Editora UFMG, 1999.

MARTINS, José de Souza. A sociabilidade do homem simples. São Paulo: Hucitec, 2000.

MARX, Karl. O Capital: crítica da economia política. São Paulo: Nova Cultural, 1985-1986.

OLIVEIRA, Francisco. Crítica a razão dualista: o ornitorrinco. São Paulo: Boitempo, 2003.

PAULANI, Leda. Brasil delivery: servidão financeira e estado de emergência econômico. São Paulo: Boitempo, 2008.

PEREIRA, Paulo Cesar Xavier. Espaço, Técnica e Construção: o desenvolvimento das técnicas construtivas e a urbanização do morar em São Paulo. São Paulo: Nobel, 1988.

PEREIRA, Paulo Cesar Xavier (org.). Reconfiguração das cidades contemporâneas: contradições e conflitos. São Paulo: FAUUSP, 2016.

Produção imobiliária e reconfiguração da cidade contemporânea. São Paulo: FAUUSP, 2017. Disponível em: <http://www.livrosabertos.sibi.usp.br/portaldelivrosUSP/catalog/ book/284>.

- Imediato, global e total na produção do espaço: financeirização da cidade de São Paulo. São Paulo: FAUUSP, 2018. Disponível em: <http://www.livrosabertos.sibi.usp.br/portaldelivrosUSP/catalog/book/302>.

PETRELLA, Guilherme. A fronteira infernal da renovação urbana em São Paulo: região da Luz noséculo XXI. Tese (Doutorado em Arquitetura e Urbanismo) - Faculdade de Arquitetura e Urbanismo, Universidade de São Paulo, São Paulo, 2017. Disponível em: <https://teses. usp.br/teses/disponiveis/16/16137/tde-29062017-132232/pt-br.php>.

, Aprendendo com a São Paulo delirante: reestruturação imobiliária, movimentos sociais e espoliação. In: PEREIRA, P.C.X. (org.). Imediato, global e total na produção do espaço: a financeirização da cidade de São Paulo no século XXI. São Paulo: FAUUSP, 2018, p. 163-195.

Renda Imobiliária e propriedade: Estrutura da renovação urbana. Revista Direito e Práxis, Ahead of print, Rio de Janeiro, 2020. Disponível em: <https://www.e-publicacoes.uerj.br/ index.php/revistaceaju/article/view/49986>. DOI: 10.1590/2179-8966/2020/49986.

PIKETTY, Thomas. O capital no século XXI. Rio de Janeiro: Intrínseca, 2014.

SADER, Eder. Quando novos personagens entraram em cena: experiências, falas e lutas dos trabalhadores da Grande São Paulo, 1970-80. Rio de Janeiro: Paz e Terra, 1988.

SMITH, Neil. Gentrificação, a fronteira e a reestruturação do espaço urbano. São Paulo: Revista GEOUSP, Espaço, Tempo, № 21, pp. 15-31, 2007.

Gentrificación urbana y desarollo desigual. Barcelona: Icária Editorial, 2015.

THOMPSON, Edwuard. Tradición, revuelta y consciencia de clase : estudios sobre la crisis de la sociedad preindustrial. Barcelona : Editorial Crítica, 1979.

TONE, Beatriz. Notas sobre a valorização imobiliária em São Paulo na era do capital fictício. São Paulo: FAUUSP, Mestrado, 2010.

WOOD, Ellen Meiksins. El concepto de clase en E. P. Thompson. Publicado en Cuadernos Políticos, número 36, Ediciones Era, México, pp.87-105, 1983. 